\title{
Women's perceptions about changes in food-related behaviours at home during COVID-19 pandemic in Chile
}

\author{
María-Fernanda Jara ${ }^{1}$, Barbara Leyton ${ }^{1}$, Carla Cuevas ${ }^{2}$ and Patricia Gálvez Espinoza ${ }^{3, *}$ \\ 'Institute of Nutrition and Food Technology (INTA), Universidad de Chile, El Líbano, Macul, Chile: 2Proyecto Fondecyt, \\ Universidad de Chile, Independencia, Chile: ${ }^{3}$ Department of Nutrition, College of Medicine, Universidad de Chile, \\ Independencia 1027, Independencia, Santiago, Chile
}

Submitted 12 February 2021: Final revision received 31 May 2021: Accepted 9 June 2021: First published online 14 June 2021

\begin{abstract}
Objective: To explore women's perceptions of changes in specific food habits at home, specifically the food budget and shopping, and food preparation, during the COVID-19 period.

Design: Non-probabilistic, exploratory study. Participants completed an online self-administered questionnaire. Perceptions of food habit changes were measured on a five-point Likert scale (strongly disagree to strongly agree). Data analysis was conducted in STATA v16.0.

Setting: Chile.

Participants: Adult women between 25 and 65 years old ( $n$ 2047).

Results: Of the participants, $72 \%$ were responsible for cooking, $69 \%$ for buying food and $85 \%$ for child care. Difficulties in organising and doing food budget works were observed in groups with a lower educational level, lower income and single mothers with children. Younger participants, dependent workers, women from biparental families with children and those in mandatory quarantine perceived more changes in their food shopping and budget management tasks. Participants more educated, with higher income and non-mandatory quarantine perceived to cook and eat healthier. Older participants perceived minor changes in their food preparation tasks at home; in contrast, more educated women and women from biparental families with children perceived more changes. If women were in charge of the kids or grocery shopping, more food environment changes were noticed.

Conclusions: Women perceived changes in their food environments. Some of these changes are perceived worse in the more vulnerable population. COVID19 presents a challenge for the food system and gender perspectives. This information should be considered in the design of food-related interventions.
\end{abstract}

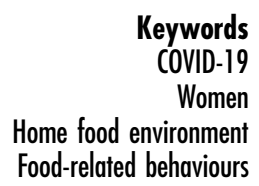

COVID-19

Women Food-related behaviours
Nowadays, the COVID-19 crisis affects every country in the world at different levels. Most countries, including Chile, have adopted extraordinary measures to avoid the spread of the virus. In March 2020, Chile started to promote sanitary measures such as a quarantine system and the reduction of people's displacements by closing schools and commercial centres. Furthermore, authorities encouraged employers to adopt flexible working hours and promote teleworking ${ }^{(1)}$. These measures carry out the disruption of people's routines which affect different areas of their lives, including food and nutrition.

The sanitary measures implemented by the authorities are adequate to prevent new COVID-19 infections.
However, they have an impact on the modification of food environments ${ }^{(2,3)}$. These food environments are understood as the contexts in which consumers relate with the food system to make their own choices about food acquisition, preparation and consumption ${ }^{(4)}$; they would daily affect routine activities that shape people's diet. Food environments are influenced by physical, political, economic, and sociocultural factors $^{(5)}$. It has been highlighted that how people relate to the food system had never been affected by such a great event as the current pandemic ${ }^{(3,6)}$, affecting the supply and demand chain of products, with the vulnerable and low-income families affected most ${ }^{(6,7)}$. Among the food environments, one that has been notoriously affected is the 
domestic food environment, defined as the one developed at home ${ }^{(8)}$. Due to the exposure of family groups to forced or voluntary quarantine, school and preschool shutdowns, teleworking, special food shopping hours, among other factors, the environment inside the houses has changed. In addition, this environment is affected by economic factors such as people losing their jobs, family structure and functioning, and stress in family members ${ }^{(9)}$, which could be magnified during lockdown periods due to social isolation, fear and uncertainty ${ }^{(10)}$. In consequence, family members could modify their food-related behaviours inside their homes. Some studies have already evaluated changes in food consumption habits during the lockdown in the USA, Europe and Chile, highlighting a rise in the general consumption of food ${ }^{(11)}$ and an increase in unhealthy food consumption $^{(2,12)}$.

Historically, from a social perspective, it is considered that women are responsible for the home food environment, including family care and domestic chores management ${ }^{(13)}$, such as food planning, grocery shopping, cooking and cleaning ${ }^{(14)}$. In Chile, before the pandemic, national reports indicated that women do more work hours (paid and not paid) than men (about $2 \mathrm{~h}$ more per day) ${ }^{(15)}$. Women spent about double the time than men, doing unpaid domestic work ${ }^{(15)}$, which has been seen in other countries in Latin America ${ }^{(16)}$. Additionally, in our country, $96 \%$ of women declared that they are the principal caregivers of their children, in comparison with only $1.4 \%$ of men ${ }^{(17)}$. The gender gap in the distribution of domestic duties is accentuated after 25 years of age, a stage of life that coincides with the most productive work period and with the years of pronounced fertility for women ${ }^{(18)}$. In the context of the current health crisis, some reports have indicated that Chilean women devoted $9 \mathrm{~h}$ more per week than men to perform tasks such as cooking, cleaning and laundry ${ }^{(19)}$; $22.23 \%$ of women increased their daily care workload by more than $8 \mathrm{~h}$, compared to $13.3 \%$ of $\operatorname{men}^{(20)}$; and $9 \%$ of women indicate that they are not doing paid work due to the need for time to care for children or sick relatives, $v$. $0.7 \%$ of $\operatorname{men}^{(18)}$.

Women have been particularly exposed to the consequences of COVID-19. More women than men have lost their jobs; most women have informal jobs such as vendors or maids, jobs that are most affected during the sanitary crisis and more gender violence has been seen during this time ${ }^{(21)}$. This, added to the extra house duties performed by women during the COVID-19 period, placed them in an especially vulnerable position while facing all the challenges of the food home environment.

Finally, modifications in the domestic food environment could influence women's role as the ones 'responsible for family feeding'. This situation could directly affect the way their families are fed and nurtured ${ }^{(22)}$, impacting food security for the entire family, which could lead to an increase in malnutrition ${ }^{(4)}$. Factors such as the loss of economic access to food, difficulty accessing healthy food and fresh products ${ }^{(3)}$, the rise of some food prices $^{(23)}$ and having all the family together most of the day at home could have a significant impact in the way women and their families manage their domestic food environment. A national survey conducted by the Chilean Government during the pandemic showed an increase in food insecurity, especially in the most impoverished homes with women as heads of the family ${ }^{(24)}$. This increase could be related to the economic crisis due to the sanitary crisis, which is also related to greater job insecurity and reduced incomes ${ }^{(24,25)}$.

Due to the novelty of the current global situation, it is interesting to study the impact of this sanitary, economic and social crisis in the domestic food environment area, considering women's perceptions of changes in their workload as they are responsible for this environment. These perceptions could contribute to understanding women's role in periods of crisis and help the public health authorities include a gender perspective in the development of policies directed to overcome malnutrition problems and food security in our population. In this context, this study investigates how the COVID-19 pandemic affects the domestic food environment in Chile by exploring women's perceptions of changes in specific food habits at home, specifically the food budget and shopping, and food preparation, during the COVID-19 period. Additionally, we explore the differences between these perceptions among women with different sociodemographic characteristics.

\section{Methods}

\section{Study design and participants}

This study was conducted with a transversal, non-probabilistic design. Adult women between 25 and 65 years old living in Chile were invited to participate voluntarily. Due to displacement restrictions derived from sanitary measures, it was decided to collect data using an anonymous and selfreported online survey, accessed through any smart device with an internet connection. In Chile, $87.4 \%$ of homes have access to the internet ${ }^{(26)}$.

This questionnaire was available for 1 month (from 15 May to 15 June 2020). The invitation to participate in this survey was promoted using the most used social media platforms among the population, such as Facebook, Instagram and WhatsApp; emails were sent to the university associates (e.g. community organisations, employees and community leaders). We received a total of 2272 answers, but after cleaning the database from duplicates and from those who did not meet inclusion criteria, we worked with data from 2047 participants. This figure was higher than the ones registered in other studies with a similar methodology ${ }^{(27,28)}$. No incentive was offered to participants for answering the questionnaire. 


\section{Data collection}

We developed a self-reported online questionnaire with closed questions. This instrument had two sections, as we described below.

\section{Evaluation of the women's perception of changes in food-related habits}

We developed a five-point Likert scale (1. strongly agree, 2. agree, 3. neither, 4 . disagree, 5 . strongly disagree) and with an option of not answering the statement. The Likert scale was divided into two subscales considering the following themes: (1) perceptions about food expenditure and purchase (eight statements); and (2) perceptions about food preparation (thirteen statements). Items for each subscale were elaborated based on previous literature in the topic and experiences suffered by women who the team works with. The statements represented possible daily situations that women could be living in during the COVID-19 pandemic time. To each answer, we assigned one to five points to the answer according to the positive or negative directionality of the statement. No score was assigned to the 'doesn't answer' option with the intention of not modifying the total number in the score obtained in each subscale. Thus, the maximum score possible to obtain for the perceptions about the food expenditure and purchase subscale was 40 points, while the subscale of perceptions about food preparation had a total of 65 points. The lower the score obtained in each subscale, the greater was the perception of changes regarding their experiences before the pandemic outbreak, meaning a worsening of the food environment.

\section{Socio-demographic variables}

Using this same instrument, socio-demographic data, such as age, the maximum educational level reached, level of income, family type, employment situation before the pandemic and place of residence, were collected. In Chile, a partial and dynamic confinement system has been implemented by geographical area, that is why participants were also consulted about their confinement status when answering the survey. Age was categorised in quartiles to facilitate the statistical analysis. The educational level was categorised into four groups: primary-secondary education, technical education (short-cycle tertiary education), undergraduate education (bachelor degree or equivalent) and postgraduate education. Incomes per home were categorised in per capita income quintiles, based on the classification used by the Ministry of Social Development and Family in Chile ${ }^{(29)}$, then this amount was calculated in American dollars (USD) using as a reference the dollar rate during the last trimester in Chile ${ }^{(30)}$. The family type was categorised into three groups: family without children, biparental family with children and single mother with children, based on the typology used by the National Statistics Institute of Chile $^{(31)}$. The employment status was categorised into three groups: employee, self-employed and unemployed. The confinement status was categorised into three groups: mandatory isolation (legally enforced), voluntary selfisolation (not legally enforced) and no isolation. Additionally, the participants were asked if they were the main ones responsible for unpaid domestic labour such as purchasing and preparing food and caring for dependent people (children and elderly) at home.

\section{Data analyses}

We used descriptive analysis for informing levels of participants' agreement with each statement; answers were grouped in three categories: 'in agreement' (answers 1 and 2), 'undecided' (answer 3) and 'in disagreement' (answers 4 and 5). The results were expressed in absolute ( $n$ ) and relative (\%) frequency tables and in the median and interquartile rate $\left(\mathrm{p}_{25}-\mathrm{p}_{75}\right)$.

Data were non-normally distributed. Therefore, to determine the association between the level in which women agree with the statements and their socio-demographic characteristics, non-parametric statistic tests were used. The scores obtained from the Likert-type scale statements were added to each section. The Mann-Whitney test was used to compare between two groups, and the Kruskal-Wallis test was used to compare three or more groups, applying the post hoc Bonferroni test afterward to determine among in which groups were the most significant result differences. Rates of $P<0.05$ were considered statistically significant. For the statistical analysis, the Stata v16.0 software was used (StataCorp.).

\section{Results}

\section{Participant's characteristics}

The women's characteristics can be found in Table 1. Median age was 36 years old $\left(\mathrm{p}_{25}\right.$ : 31 years old $-\mathrm{p}_{75}: 44$ years old). A high percentage of the sample lived in the central zone of the country (87\%), had undergraduate or graduate studies (86\%), a high rate of income (66\%), were performing paid work before the pandemic (86\%) and belonged to families with sons or daughters (60\%). A $93.5 \%$ of the sample was on voluntary or mandatory isolation at the moment of answering the survey.

Regarding the unpaid domestic work and care, the women from this sample were the ones primarily responsible for cooking (72\%) and buying food (69\%). In homes with children, it was observed that women were also in charge of the childcare ( $85 \%$ ), and this was a higher percentage in biparental families (86.5\%) compared to single-parent families (81.4\%). Finally, $46 \%$ of the surveyed women stated that they had maids to help with the home tasks before the pandemic, which dropped to $9 \%$ during the lockdown. 
Table 1 Socio-demographic characteristics of participants (n 2047)

\begin{tabular}{|c|c|c|}
\hline & $n$ & $\%$ \\
\hline \multicolumn{3}{|l|}{ Age (years) } \\
\hline $25-34$ & 890 & 43.48 \\
\hline $35-44$ & 681 & $33 \cdot 37$ \\
\hline $45-54$ & 294 & $14 \cdot 36$ \\
\hline$>55$ & 182 & $8 \cdot 89$ \\
\hline \multicolumn{3}{|l|}{ Residence area } \\
\hline Centre & 1781 & 87.01 \\
\hline South & 224 & $10 \cdot 94$ \\
\hline North & 42 & 2.05 \\
\hline \multicolumn{3}{|l|}{ Education level } \\
\hline Primary-secondary & 71 & 3.47 \\
\hline Technical education & 221 & $10 \cdot 80$ \\
\hline University & 1082 & $52 \cdot 86$ \\
\hline Postgraduate & 673 & $32 \cdot 87$ \\
\hline \multicolumn{3}{|l|}{ Quintile of monthly income per capita } \\
\hline I and II (<211 USD per capita) & 218 & $10 \cdot 73$ \\
\hline III (212-324 USD per capita) & 184 & 9.06 \\
\hline IV (325-555 USD per capita) & 282 & 13.88 \\
\hline V (> 556 USD per capita) & 1347 & $66 \cdot 32$ \\
\hline \multicolumn{3}{|l|}{ Family type } \\
\hline No children & 826 & 40.43 \\
\hline Couple with children & 943 & $46 \cdot 16$ \\
\hline Lone mother with children & 274 & 13.41 \\
\hline \multicolumn{3}{|l|}{ Employment status } \\
\hline Employee & 1348 & $67 \cdot 61$ \\
\hline Self-employee & 368 & 17.98 \\
\hline Unemployed & 295 & 14.41 \\
\hline \multicolumn{3}{|l|}{ Confinement status } \\
\hline Mandatory isolation (legally enforced) & 1055 & 51.54 \\
\hline Voluntary self-isolation (not legally enforced) & 858 & 41.91 \\
\hline No isolation & 134 & 6.55 \\
\hline
\end{tabular}

Perceptions about food expenditure and purchase

A $42.7 \%$ of the surveyed women perceived greater difficulties managing and organising the budget during the pandemic period, and $48.02 \%$ of them stated to have looked for new strategies to make their budget work (online supplementary material, Supplemental Appendix 1). In both statements, women from low educational level $(P<0.001)$, with a lower income $(P<0.001)$ and single mothers with children $(P<0.001)$ perceived more difficulties and economic challenges while accessing food. No significant differences were found among groups of different age, employment status or confinement status.

Regarding food shopping, most of the participants perceived to have spent more money on food (67.12\%) and buying more significant amounts of food (71.47\%) compared to the period before COVID-19 (online supplementary material, Supplemental Appendix 1). Women from groups with a lower age $(P<0.001)$ and dependent workers $(P<0.001)$ perceived spending more money and buying more food. In terms of physical access to food, most of them stated that it was harder for them to go out and shop $(72.94 \%)$, and more than half of the sample declared to have used digital platforms with delivery service to buy food (51.93\%). Participants with a higher educational level $(P<0.001)$, with a higher income $(P<0.001)$, from biparental families with children $(P<0.001)$ and with enforced isolation $(P<0.001)$ perceived more difficulties to go out to shop and, then, they used more digital tools for getting food. No significant differences were found among other socio-economic variables.

The total median score in the food expenditure and purchase section was $20\left(\mathrm{p}_{25}: 15-\mathrm{p}_{75}: 25\right)$. The median score according to the different socio-demographic variables can be observed in Table 2. According to the participants' age group $(P<0.05)$, different perceptions were observed; young women between 25 and 34 years old perceived more significant changes compared to women over 55 years old. It was observed that women from biparental homes with children perceived more changes than women from homes without children $(P<0.05)$; women who were dependent workers were the ones who perceived more changes $(P<0.05)$; the same situation was observed in women in a legally enforced isolation $(P<0.05)$ (Table 2). There were no significant differences when comparing among women of different educational levels nor income levels.

In the analysis of the total score obtained in this scale, according to variables related to domestic work and unpaid childcare, it was observed that women who oversaw childcare perceived more changes than women who were not in charge of children $(P<0.001)$. In addition, women in charge of food shopping perceived more changes in their routines during the lockdown than those who were not in charge of it $(P<0.05)$ (Table 3$)$.

\section{Perceptions about food cooking and preparation}

Regarding food cooking and preparation, most of the women perceived that they had cooked more (78.02\%), had spent more time in the kitchen (78.60\%), had prepared different meals during the day (66.49\%) and had spent more time thinking about which meals to prepare (66.15\%) than before the pandemic (online supplementary material, Supplemental Appendix 1). Women from the older age group $(P<0.001)$, of lower educational levels $(P<0.001)$, from low-income levels $(P<0.001)$, women without children $(P<0.001)$, self-employed women $(P<0.001)$ and those without isolation $(P<0.001)$ perceived fewer changes in their routines related to these topics.

In terms of their diet quality, most of these women agreed in their perception of having prepared more home-cooked meals than before (79.04\%). However, $47.8 \%$ perceived having a healthier diet at the survey time than before the COVID-19 period (online supplementary material, Supplemental Appendix 1). Women with a higher educational level $(P<0.001)$, with a higher income level $(P<0.001)$ and those who were in quarantine (voluntary or mandatory; $P<0.05$ ) perceived that they were eating healthier during pandemic period than the comparison groups. No other differences were found between groups of different ages, family types or employment status.

The total median score in this section scale was 36 $\left(\mathrm{p}_{25}: 30-\mathrm{p}_{75}: 43\right)$. The median score according to the different socio-demographic variables can be observed in 
Table 2 Total score obtained in the food shopping and budget scale, and the food cooking and preparation scale by socio-economic variables (n 2047)

\begin{tabular}{|c|c|c|c|c|}
\hline & \multicolumn{2}{|c|}{$\begin{array}{l}\text { Total score in the food shopping and } \\
\text { feeding budget scale }\end{array}$} & \multicolumn{2}{|c|}{$\begin{array}{l}\text { Total score in the food cooking } \\
\text { and preparation scale }\end{array}$} \\
\hline & Median & $\mathrm{p}_{25}-\mathrm{p}_{75}$ & Median & $\mathrm{p}_{25}-\mathrm{p}_{75}$ \\
\hline \multicolumn{5}{|l|}{ Age (years)* } \\
\hline $25-34$ & 19 & $15-25^{a}$ & 36 & $30-43^{a, b}$ \\
\hline $35-44$ & 20 & $15-25^{\mathrm{a}, \mathrm{b}}$ & 35 & $29-42^{a}$ \\
\hline $45-54$ & 20 & $15-26^{a, b}$ & 37 & $30-45^{b}$ \\
\hline$>55$ & 21 & $16-28^{b}$ & 41 & $34-46^{c}$ \\
\hline$P$-value & 0.0180 & & 0.0001 & $<0.001$ \\
\hline \multicolumn{5}{|l|}{ Education level* } \\
\hline Primary-secondary & 21 & $14-33$ & 41 & $31-48^{a}$ \\
\hline Technical education & 20 & $15-26$ & 38 & $31-45^{a, b}$ \\
\hline University & 20 & $15-25$ & 36 & $30-43^{b}$ \\
\hline Postgraduate & 19 & $15-25$ & 35 & $30-42^{b}$ \\
\hline$P$-value & 0.2800 & & 0.0020 & \\
\hline \multicolumn{5}{|l|}{ Monthly income per capita* } \\
\hline$<211$ USD per capita & 20 & $15-26$ & 37 & $30-45$ \\
\hline 212-324 USD per capita & 19 & $15-25 \cdot 5$ & 37 & $29-45$ \\
\hline 325-555 USD per capita & 20 & $16-25$ & 37 & $29-44$ \\
\hline > 556 USD per capita & 20 & $15-25$ & 36 & $30-43$ \\
\hline$P$-value & 0.6609 & & 0.6399 & \\
\hline \multicolumn{5}{|l|}{ Family type* } \\
\hline No children & 20 & $15-26^{a}$ & 39 & $32-45^{\mathrm{a}}$ \\
\hline Couple with children & 19 & $14-24^{b}$ & 34 & $29-41^{b}$ \\
\hline Lone mother with children & 19.5 & $14-25^{a, b}$ & 36 & $29-45^{c}$ \\
\hline$P$-value & 0.0012 & & 0.0001 & $<0.001$ \\
\hline \multicolumn{5}{|l|}{ Employment status* } \\
\hline Employee & 19 & $15-25^{a}$ & 36 & $30-43^{\mathrm{a}}$ \\
\hline Self-employee & 20 & $15-27^{b}$ & 38 & $31-46^{b}$ \\
\hline Unemployed & 20 & $16-25^{a, b}$ & 36 & $30-42^{\mathrm{a}}$ \\
\hline$P$-value & 0.0340 & & 0.0088 & \\
\hline \multicolumn{5}{|l|}{ Confinement status* } \\
\hline Mandatory isolation & 19 & $14-25^{a}$ & 36 & $30-43^{a}$ \\
\hline Voluntary self-isolation & 20 & $15-25^{b}$ & 36 & $30-43^{a}$ \\
\hline No isolation & 20 & $17-26^{a, b}$ & 40 & $34-45^{\mathrm{b}}$ \\
\hline$P$-value & 0.0333 & & 0.0016 & \\
\hline
\end{tabular}

$p_{25}$ : percentile $25 ; p_{75}$ : percentile 75 .

${ }^{*} P$-value presented is for the Kruskal-Wallis test for a difference in perceptions among the categories in socio-demographic characteristics. Bonferroni test was used for multiple comparison.

a,b,cMedian values within a cell column with unlike superscript letters were significantly different at $P<0.05$ level.

Table 2. For this section scale, differences were observed in the perception of women from different ages $(P<0.001)$; women over 55 years old perceived fewer changes compared with the other age groups. Also, in this scale, differences were found between groups of varying educational levels $(P<0.05)$ and of varying family types $(P<0 \cdot 001)$. Women with a higher education level and women from biparental homes with children obtained lower scores, meaning that they perceived more significant changes in their food preparation routines. We also found differences according to their employment status $(P<0.05)$ and their confinement status $(P<0.05)$, with self-employed women workers and those who are not in isolation perceiving fewer changes in their food preparation routines (Table 2). There were no significant differences for this section scale when comparing the score values with different income levels.

In the analysis of the total score obtained in this scale according to variables related to domestic work and unpaid childcare, significant differences in perception were observed between women who oversaw childcare and the ones who did not $(P<0.001)$, as among those who were in charge of food shopping $(P<0.05)$ or food cooking $(P<0.001)$ and those who were not (Table 3). It was shown that women who stated being in charge of these domestic work and childcare duties were the ones who perceived more changes in their food preparation habits during the lockdown.

\section{Discussion}

This research aimed to explore women's perceptions about the impact of COVID-19 lockdown in their home food environment, specifically regarding the task of buying and preparing food. To our knowledge, this is a pioneer study about the effects of the COVID-19 pandemic in people's homes from the women's point of view, especially in Latin America. In this way, this study contributes to understanding changes in specific food-related habits during a crisis that includes long lockdown periods. 
Table 3 Total score obtained in the food shopping and budget scale, and the food cooking and preparation scale by the housework tasks ( $n$ 2047)

\begin{tabular}{|c|c|c|c|c|}
\hline & \multicolumn{2}{|c|}{$\begin{array}{c}\text { Total score in the food } \\
\text { shopping and feeding } \\
\text { budget scale }\end{array}$} & \multicolumn{2}{|c|}{$\begin{array}{l}\text { Total score for the item } \\
\text { of food cooking and } \\
\text { preparation scale }\end{array}$} \\
\hline & Median & $\mathrm{p}_{25}-\mathrm{p}_{75}$ & Median & $\mathrm{p}_{25}-\mathrm{p}_{75}$ \\
\hline \multicolumn{5}{|c|}{ Children primary caregiver* } \\
\hline Yes & 19 & $14-24$ & 34 & $28-41$ \\
\hline No & 20 & $16-26$ & 39 & $33-45$ \\
\hline$P$-value & 0.0000 & $<0.001$ & 0.0000 & $<0.001$ \\
\hline \multicolumn{5}{|c|}{ Elderly primary caregiver* } \\
\hline Yes & 19 & $14.5-24.5$ & 37 & $30-43$ \\
\hline No & 20 & $15-25$ & 36 & $30-43$ \\
\hline$P$-value & 0.3673 & & 0.8890 & \\
\hline \multicolumn{5}{|c|}{ Main in charge of buying* } \\
\hline Yes & 19 & $15-25$ & 36 & $30-43$ \\
\hline No & 20 & $16-26$ & 37 & $31-44$ \\
\hline$P$-value & 0.0047 & & 0.0297 & \\
\hline \multicolumn{5}{|c|}{ Main in charge of cooking* } \\
\hline Yes & 19 & $15-25$ & 35 & $29-42$ \\
\hline No & 20 & $15-26$ & 41 & $33-45$ \\
\hline$P$-value & 0.1591 & & 0.0000 & $<0.001$ \\
\hline
\end{tabular}

p25: percentile 25; p75: percentile 75 .

${ }^{*} P$-value presented is for the Mann-Whitney test for a difference in perceptions among the categories in distribution of housework and unpaid care tasks. Median values were significantly different at $P<0.05$ level.

This study confirms that most women were in charge of unpaid tasks related to caring and home management during this pandemic period. We found that most of the surveyed women put themselves as the person in charge of the tasks of buying food (69\%), cooking food (72\%) and child caring ( $85 \%)$. This women's role inside the family was already observed before the COVID-19 period $^{(32)}$, and it has been recently described in other studies conducted in Europe ${ }^{(28-30)}$, during this pandemic period. Evidence has suggested that part of the home tasks can be shared between men and women. However, most of the extra work during the pandemic period has fallen on women $^{(33-36)}$. Concern has been expressed in this regard since the increase of domestic tasks and caring workload can impact women's ability to perform a remunerated $\mathrm{job}^{(33,37)}$. A survey conducted during the pandemic in thirteen countries of Latin America and the Caribbean, including Chile, shows that women are more likely to lose their jobs than men, due to the increase in childcare tasks and the social norms that make women the primary ones responsible for those tasks ${ }^{(38)}$. These difficulties for having paid jobs could be diminishing the total family income, particularly in families with children of preschool age who cannot independently undertake distance education ${ }^{(39)}$. Besides, this heavy unpaid workload leads to higher levels of stress and other mental health problems ${ }^{(37)}$. In Chile, $55.8 \%$ of women indicate that their mental health has worsened during the months of the health crisis, while only $42.8 \%$ of men estimate the aforesaid ${ }^{(21)}$. This study did not collect information from men to compare how they are affected by the pandemic time. Future studies should consider men's opinions on how this period has affected their contribution to the household chores.

Women perceived their home food environment as having changed during this pandemic period. Younger participants and those in quarantine perceived more food environment changes, having more food budget and preparation problems. Other food environments in constant relationship with the home food environment have also been affected by this pandemic ${ }^{(40-43)}$. Therefore, it is understandable that women perceived more difficulties reaching different food environments during the lockdown. These changes in food environments were perceived as the worst by younger women, with a more frequent need to cook. In this sense, results from research conducted in Europe showed that older adults perceived fewer changes in their eating routines ${ }^{(11,44)}$. However, in these European studies, most older participants were older than 65 years old (older than our participants); they could have had similar food routines at home before the pandemic. In our study, it is likely that women over 55 years old had more experience managing home tasks than younger participants. Additionally, probably younger women are more used to eating out, and during the pandemic, restaurants (as part of one of the food environments ${ }^{(8)}$ ) have limited capacity to work; in consequence, younger women are forced to manage food more at home. Data from the USA indicated that people from 20 to 29 years old are those who eat more calories from food outside their houses ${ }^{(45)}$.

Our participants noted changes in their routines to acquire food, manage the food budget, and in food cooking and preparation habits. Women in our sample who were from lower educational levels, lower incomes and single mothers with children perceived to have faced more significant financial difficulties accessing food. This finding is correlated with the data provided by the Government of Chile in which it was demonstrated that more disadvantaged groups are the ones that suffer more food insecurity ${ }^{(39,46)}$. Similar evidence has been shown globally, leaving the most impoverished people more greatly affected by changes in the food system, especially in the food access due to COVID-19 ${ }^{(7)}$. This situation is worse in homes with women as head of the household, having a greater probability of suffering food insecurity on all its levels ${ }^{(22,46,47)}$. This finding highlights the importance of securing food access to the most vulnerable groups and the relevance of incorporating gender perspectives when developing public policies related to this topic.

It is interesting to highlight that even when our sample skewed towards highly educated and high socio-economic households' women, they still perceived changes during this quarantine. It is probable that this situation is because most women in our sample were used to working outside of home most of the day or having a helper who did most of the house duties. But due to sanitary measures, they have to be at home all day with no helper, doing the paid and unpaid work at the same time. 
On the other hand, it has been shown that most women declared to have prepared more homemade meals (79.04\%), and only a small number of women declared to have increased their consumption of fast-food meals (12.70\%). The tendency to cook more and the minor consumption in restaurants or the minor consumption of fast food have been shown also in European countries ${ }^{(48)}$ and in a study of families from the USA ${ }^{(2)}$ and Canada ${ }^{(49)}$. This trend could be taken as an opportunity to improve the diet quality through food and nutrition education. However, there is no certainty that these habits will continue once the sanitary measures start to ease.

Although most women from this study declared cooking more homemade meals, less than half of the participants ( $47.78 \%)$ perceived to be eating healthier. This situation was perceived as worse by women with lower incomes. Another study in Chile showed similar results. In this, women declared eating more food than before the pandemic, and only $35 \%$ of them perceived having a healthier diet, although most of them declared cooking more at home ${ }^{(12)}$. In a study conducted in UK adults, most surveyed participants indicated having worse diets and having problems with weight managing strategies during the pandemic, especially in those with higher BMI ${ }^{(50)}$. Mental health problems were also associated with overeating during lockdown ${ }^{(50)}$. Additionally, a recent study reported that the increase of energy consumption during the lockdown was higher in women than men ${ }^{(51)}$. All this evidence is relevant considering that in Chile, as in other parts of the world, obesity and morbid obesity prevalence is higher in women than in men ${ }^{(52)}$, and it is expected that, due to the extensive lockdown, obesity issues could be exacerbated in the adult population ${ }^{(53)}$. Furthermore, concern has been expressed regarding eating habits because the consumption of unhealthy diets impacts susceptibility to COVID-19 and recovery ${ }^{(54)}$.

Finally, in the current study, women who were the primary caregivers of children perceived more changes in their food-related behaviours than women who were not. Women from biparental families with children seemed to be the most affected by the COVID-19 pandemic. As schools have been closed during the pandemic period, children are at home all day with their mother taking care of them. A similar situation happened with women's partners: some are teleworking from home, and others lost their job. Consequently, women probably are taking care of both children and partners during the COVID-19 period. Some evidence has shown that during quarantine periods, parents, especially mothers, are under stressful experiences trying to balance their work, personal lives and care for their children ${ }^{(55)}$. Also, as parents are losing their jobs, family, and especially mothers, could be more worried about feeding their family. Another study that evaluated changes in families' home food environments shows an increased parents' concern about children becoming overweight and thus increased controlling feeding practices during the confinement, especially in families with low food security reported ${ }^{(2)}$. These findings highlight the importance of supporting programmes and policies that provide access to nourishing meals to families with children.

Facing the post-pandemic period seems a challenge; policies with a gender approach should be implemented by the governments. For example, educational campaigns must reinforce the role of the whole family in the house tasks, not just women. Companies should understand that women have this double burden of work and should implement some measures for allowing women more flexibility in the office hours without affecting their salaries or job status, especially in households where young children are present. In this same sense, there have been recommendations for ensuring universal access to childcare centres where children also can receive food during the day ${ }^{(18)}$. Governments should create laws to protect women's jobs $^{(21)}$. Furthermore, it has been recommended to give direct economic incentives to women for helping them to face home food environment challenges during and after the pandemic ${ }^{(21)}$. Reinforcing food subsidies would also contribute to facing the food insecurity that can happen as a consequence of the COVID-19 crisis.

Even though this research provides useful data for making future decisions, it has some limitations similar to those from other studies with an online methodology. The first limitation is that we created the instrument for reaching the study goal, and it has not been validated before. A second limitation is related to the population who could access this survey. Since the primary access was through a device with an internet connection, this could have limited the participation of women from more vulnerable groups who may not have had the resources to access the survey while it was available. It is necessary to evaluate other methodologies to collect information from these populations who are at a higher risk of food insecurity and other health problems due to the pandemic. Finally, even though the sample is larger than others from similar studies, it was not reached through a probabilistic sample, with groups with lower educational level and lower incomes underrepresented if the sample distribution is compared to the reality of the country ${ }^{(56)}$. Consequently, the results of this study should be analysed with caution.

\section{Conclusions}

Women from our study perceive changes in their home food environment. Younger women, women in quarantine, women who were dependant workers and those from biparental homes with children perceived more changes than their counterparts regarding their food environment. Women from the low-incomes and low-education categories stated having faced more difficulties managing their food budget during the pandemic. These women 
perceived fewer changes in their food preparation tasks at home. Women who were in charge of the domestic tasks declared having perceived more changes in their food environment.

The COVID-19 pandemic and the measures to prevent its spread present a variety of challenges for the families. As the main person in charge of the home food environment, women face several difficulties interacting with other food environments and the food system. This interaction seems worst in women from low socio-economic levels. This situation should be addressed from an interdisciplinary perspective to guarantee the availability, accessibility and affordability of a healthy diet to all families in crisis periods. Additionally, these aspects should alert authorities and healthcare planners about the importance of including gender perspectives during the development of food interventions during the pandemic and future periods of sanitary, economic or social crisis.

\section{Acknowledgements}

Acknowledgements: The authors would like to thank Christine Etchart and Brian Boyle for their assistance in the manuscript translation and English edition. Financial support: This research received no specific grant from any funding agency, commercial or not-for-profit sectors. Conflict of interest: There are no conflicts of interest. Authorship: M.-F.J.: statistical data analyses; writing manuscript. B.L.: data curation and statistical data analyses; manuscript revision. C.C.: study design; questionnaire design; manuscript revision. P.G.: study design; conceptualisation of overarching research goals and aims; questionnaire design; writing manuscript. Ethics of human subject participation: This study was conducted according to the guidelines laid down in the Declaration of Helsinki, and all procedures involving research study participants were approved by the Ethics Committee of Investigation on Humans (CEISH) at the College of Medicine, University of Chile. All participants provided informed consent, after having read the study information.

\section{Supplementary material}

For supplementary material accompanying this paper visit https://doi.org/10.1017/S1368980021002639

\section{References}

1. Ministerio de Salud. Gobierno de Chile (2020) CoronavirusCOVID-19 action plan. https://www.gob.cl/coronavirus/ plandeaccion/ (accessed June 2021).
2. Adams EL, Caccavale LJ, Smith D et al. (2020) Food insecurity, the home food environment, and parent feeding practices in the era of COVID-19. Obesity 28, 2056-2063.

3. United Nations System Standing Committee on Nutrition (2020) Food environments in the COVID-19 pandemic. https:// www.unscn.org/en/news-events/recent-news?idnews $=2040$ (accessed January 2021).

4. Turner C, Aggarwal A, Walls H et al. (2018) Concepts and critical perspectives for food environment research: a global framework with implications for action in low- and middleincome countries. Glob Food Sec 18, 93-101.

5. The High Level Panel of Experts on Food Security and Nutrition (2017) Nutrition and food systems. A report by the high level panel of experts on food security and nutrition of the committee on world food security. http://www.fao. $\mathrm{org} / \mathrm{cfs} / \mathrm{cfs}$-hlpe (accessed January 2021).

6. Torero M (2020) Without food, there can be no exit from the pandemic. Nature 580, 588-589.

7. The High Level Panel of Experts on Food Security and Nutrition (2020) Impact of COVID-19 on Food Security and Nutrition (FSN). http://www.fao.org/fileadmin/ templates/cfs/Docs1920/Chair/HLPE_English.pdf (accessed January 2021).

8. Cerda R, Egaña D, Galvez P et al. (2015) Conceptual Framework on the Conditioning Factors of Food Environments in Chile. Santiago, Chile. http://www. bibliotecaminsal.cl/marco-conceptual-sobre-los-factorescondicionantes-de-los-ambientes-alimentarios-en-chile/ (accessed September 2020).

9. Brock RL \& Laifer LM (2020) Family science in the context of the COVID-19 pandemic: solutions and new directions. Fam Process 59, 1007-1017.

10. Brooks SK, Webster RK, Smith LE et al. (2020) The psychological impact of quarantine and how to reduce it: rapid review of the evidence. Lancet 395, 912-920.

11. Renzo D, Med JT, Di RL et al. (2020) Eating habits and lifestyle changes during COVID-19 lockdown: an Italian survey. J Transl Med 18, 229-243.

12. Reyes-Olavarría D, Latorre-Román PÁ, Guzmán-Guzmán IP et al. (2020) Positive and negative changes in food habits, physical activity patterns, and weight status during Covid19 confinement: associated factors in the Chilean population. Int J Environ Res Public Health 17, 1-14.

13. Martin MA \& Lippert A (2013) Feeding her children, but risking her health: the intersection of gender, household food insecurity and obesity. Soc Sci Med 74, 1754-1764.

14. DeVault ML (1991) Feeding the Family: The Social Organization of Caring as Gendered Work. Chicago, IL: University of Chicago Press.

15. Instituto Nacional de Estadística (2016) National Survey of Time Use 2015, Main Results Document. https://www.ine.cl/docs/ default-source/uso-del-tiempo-tiempo-libre/publicaciones-yanuarios/publicaciones/documento_resultados_enut.pdf? sfvrsn=cf66dad0_7 (accessed May 2021).

16. Gender Equality Observatory for Latin America and the Caribbean (n.d) Unpaid working time according to own income by sex. https://oig.cepal.org/es/indicadores/tiempotrabajo-no-remunerado-segun-ingresos-propios-sexo (accessed May 2021).

17. Ministerio de Desarrollo Social \& Gobierno de Chile (2017) Results of the Third Longitudinal Survey of Early Childhood. http://www.creciendoconderechos.gob.cl/docs/ ELPI-PRES_Resultados_2017.pdf (accessed January 2021).

18. Buitrago-Hernández S \& Bronfman-Horovitz J (2021) Ten Messages about COVID-19 and Female Work in Chile: Impacts and Challenges. Washington, D.C.: World Bank Group. http://documents.worldbank.org/curated/en/45912161 3117667549/Diez-Mensajes-Sobre-COVID-19-y-TrabajoFemenino-en-Chile-Impactos-y-Desafíos (accessed May 2021). 
19. Ministerio de la Mujer y la Equidad de Género \& Gobierno de Chile (2020) Proposal by the Women's Council. Covid-19. https://juntasenaccion.cl/wp-content/uploads/2020/10/ Propuestas-Consejo-Mujer-Covid-19.pdf (accessed May 2021).

20. Universidad de Chile \& Colegio Médico de Chile (2020) What's has been the impact of the pandemic on care work? An analysis from a gender perspective. https://www. movid19.cl/publicaciones/once-informe/once-informe.pdf (accessed May 2021).

21. Universidad de Chile \& Colegio Médico de Chile (2020) How can we reduce the negative effect of the health crisis for women and health workers? A look from a gender perspective. https://www.movid19.cl/publicaciones/quinto-informe/ quinto-informe.pdf (accessed May 2021).

22. Hanson KL, Sobal J \& Frongillo EA (2007) Gender and marital status clarify associations between food insecurity and body weight. J Nutr 137, 3-8.

23. Fortuna A, Oreamuno MAA, Maria G et al. (2020) Food outlook. Biannual report on global food markets. http://www. fao.org/documents/card/en/c/ca9509en/ (accessed January 2021).

24. Ministerio de Desarrollo Social y Familia \& Gobierno de Chile (2020) COVID-19 Social Survey. Summary of main results. http://observatorio.ministeriodesarrollosocial.gob.cl/vizdata/ covid19/index.html (accessed December 2020).

25. Ministerio de Desarrollo Social y Familia \& Gobierno de Chile (2017) Food insecurity. Summary of results. http:// observatorio.ministeriodesarrollosocial.gob.cl/storage/docs/ casen/2017/CASEN_2017_Inseguridad_alimentaria.pdf (accessed December 2020).

26. OECD (2019) How's life in the digital age? Opportunities and risks of the digital transformation for people's well-being. https://www.oecd.org/publications/how-s-life-in-the-digitalage-9789264311800-en.htm (accessed December 2020).

27. Balani R, Herrington H, Bryant E et al. (2019) Nutrition knowledge, attitudes, and self-regulation as predictors of overweight and obesity. J Am Assoc Nurse Pract 31, 502-510.

28. Tierney M, Gallagher AM, Giotis ES et al. (2017) An online survey on consumer knowledge and understanding of added sugars. Nutrients $\mathbf{9}, 1-13$.

29. Ministerio de Desarrollo Social y Familia \& Gobierno de Chile (2018) Poverty and income distribution. Results presentation. http://www.pleyades.cl/wp-content/uploads/2018/08/ Presentacion_Sintesis_de_Resultados_Casen_2017.pdf (accessed December 2020).

30. Banco Central de Chile (2020) Statistical data base. Exchange rate. https://si3.bcentral.cl/Siete/ES/Siete/Cuadro/ CAP_TIPO_CAMBIO/MN_TIPO_CAMBIO4/DOLAR_OBS_ ADO? cbFechaInicio $=2007 \& \mathrm{cbFechaTermino}=2020 \& \mathrm{cb}$ Frecuencia $=$ QUARTERLY\&cbCalculo $=$ NONE\&cbFechaBase $=$ (accessed December 2020).

31. Instituto Nacional de Estadísticas (2018) Glossary by subject. CENSUS 2017. http://resultados.censo2017.cl/download/ Glosario.pdf (accessed December 2020).

32. Comunidad Mujer (2019) How much do we contribute to GDP? First national study of the economic valuation of household work and unpaid care in Chile. https://www. comunidadmujer.cl/biblioteca-publicaciones/wp-content/ uploads/2020/03/Cuánto-aportamos-al-PIB.-Estudio-deValoración-Económica-del-TDCNR-en-Chile.pdf (accessed January 2021).

33. Oggero N, Rossi MC, Del Boca D et al. (2020) Women's work, housework, and childcare before and during COVID-19. IZA Institute of Labor Economics. https://www. iza.org/publications/dp/13409/womens-work-houseworkand-childcare-before-and-during-covid-19 (accessed January 2021).

34. Farré L, Fawaz Y, González L et al. (2020) How the COVID-19 lockdown affected gender inequality in paid and unpaid work in Spain. IZA Discussion Paper. https://www.iza.org/ publications/dp/13434/how-the-covid-19-lockdown-affectedgender-inequality-in-paid-and-unpaid-work-in-spain (accessed January 2021).

35. Sevilla A \& Smith S (2020) Baby steps: the gender division of childcare during the COVID-19 pandemic. IZA DP No. 13302. IZA Institute of Labor Economics. http://ftp.iza.org/ dp13302.pdf (accessed January 2021).

36. Del Boca D, Oggero N, Profeta P et al. (2020) Women's and men's work, housework and childcare, before and during COVID-19. Rev Econ Househ 18, 1001-1017.

37. The World Bank Group (2020) Gender dimensions of the COVID-19 pandemic. https://openknowledge.worldbank. org/bitstream/handle/10986/33622/Gender-Dimensions-ofthe-COVID-19-Pandemic.pdf? sequence $=1$ \&isAllowed $=\mathrm{y}$ (accessed January 2021).

38. Cucagna E \& Romero J (2021) The Gendered Impacts of COVID19 on Labor Markets in Latin America and the Caribbean. Washington, D.C.: World Bank Group. http://documents1. worldbank.org/curated/en/675641612934705667/pdf/TheGendered-Impacts-of-COVID-19-on-Labor-Markets-in-LatinAmerica-and-the-Caribbean.pdf (accessed January 2021).

39. Brito C, Franch C, Ivanovic C et al. (2020) Differential impact of the COVID-19 pandemic on women and its connection to the pillars of the agrifood system. No. Santiago, Chile. http:// www.fao.org/publications/card/es/c/CB2115EN (accessed January 2021).

40. Helble M (2020) Economic strategies to promote healthy food environments mid the COVID-19 Pandemic. https://www.who. int/docs/default-source/searo/ncd/dr-matthias-economicstrategies-to-promote-healthy-food-environments-in-thecontext-of-covid-19.pdf?sfvrsn=89012edc_4 (accessed January 2021).

41. Chang M, Green L \& Cummins S (2020) All change. Has COVID-19 transformed the way we need to plan for a healthier and more equitable food environment? Urban Des Int 19, 1-5.

42. Egaña Rojas D, Rodriguez Osiac L \& Galvez Espinoza P (2020) Food in Times of COVID-19 Pandemic. Santiago de Chile: Escuela de Salud Pública - Universidad de Chile. https://libros.uchile.cl/files/presses/1/monographs/1157/ submission/proof/index.html\#110 (accessed January 2021).

43. Rippin HL, Wickramasinghe K, Halloran A et al. (2020) Disrupted food systems in the WHO European region - a threat or opportunity for healthy and sustainable food and nutrition? Food Secur 12, 859-864.

44. Poelman MP, Gillebaart M, Schlinkert C et al. (2021) Eating behavior and food purchases during the COVID-19 lockdown: a cross-sectional study among adults in the Netherlands. Appetite 157, 105002

45. USDA (2014) What we eat in America - dietary survey: data collection, interpretation, dissemination, and methodology. https://reeis.usda.gov/web/crisprojectpages/0426312-whatwe-eat-in-america-dietary-survey-data-collection-interpretationdissemination-and-methodology.html (accessed September 2020).

46. Instituto Nacional de Estadísticas (2020) Statistical Bulletin: Quarterly Employment. https://www.ine.cl/docs/defaultsource/ocupacion-y-desocupacion/boletines/2020/país/boletínempleo-nacional-trimestre-móvil-febrero-marzo-abril-2020.pdf (accessed September 2020).

47. Bawadi HA, Tayyem RF, Dwairy AN et al. (2012) Prevalence of food insecurity among women in Northern Jordan. J Heal Popul Nutr 30, 49-55.

48. The Nielsen (2020) While still in lockdown, many Europeans expect the impact of COVID-19 to last another year. https:// www.nielsen.com/us/en/insights/article/2020/while-still-inlockdown-many-europeans-expect-the-impact-of-covid-19to-last-another-year/ (accessed January 2021). 
49. Carroll N, Sadowski A, Laila A et al. (2020) The impact of Covid-19 on health behavior, stress, financial and food security among middle to high income Canadian families with young children. Nutrients 12, 1-14.

50. Robinson E, Boyland E, Chisholm A et al. (2021) Obesity, eating behavior and physical activity during COVID-19 lockdown: a study of UK adults. Appetite 156, 104853.

51. Bhutani S, Cooper J \& Vandellen M (2020) Self-reported changes in energy balance behaviors during COVID-19 related home confinement: a cross-sectional Study. medRxiv. https://www.medrxiv.org/content/10.1101/2020. 06.10.20127753v1 (accessed January 2021).

52. Ministerio de Salud \& Gobierno de Chile (2017) National Health Survey 2016-2017. First results. http://web.minsal.
cl/wp-content/uploads/2017/11/ENS-2016-17_PRIMEROSRESULTADOS.pdf (accessed January 2021).

53. Bhutani S \& Cooper J (2020) COVID-19-related home confinement in adults: weight gain risks and opportunities. Obesity 28, 1576-1577.

54. Butler MJ \& Barrientos RM (2020) The impact of nutrition on COVID-19 susceptibility and long-term consequences. Brain Behav Immun 87, 53-54.

55. Spinelli M, Lionetti F, Pastore M et al. (2020) Parents' stress and children's psychological problems in families facing the COVID-19 outbreak in Italy. Front Psychol 11, 1-7.

56. Instituto Nacional de Estadísticas (2018) Summary of results, Census 2017. https://www.censo2017.cl/descargas/home/ sintesis-de-resultados-censo2017.pdf (accessed September 2020). 